\title{
Effect of Different Bonding Strategies on Adhesion to Deep and Superficial Permanent Dentin
}

Rafael Eduardo Fernandes Pegadoa

Flávia Lucisano Botelho do Amaral ${ }^{\mathrm{b}}$

Flávia Martão Flórioc

Roberta Tarkany Basting ${ }^{d}$

\section{ABSTRACT}

Objectives: To evaluate the effect of different bonding strategies on the microtensile bond strength to deep and superficial permanent dentin.

Methods: Forty-eight teeth were randomly flattened according to the dentin depth: superficial dentin (SD) and deep dentin (DD). Subsequently, three adhesive systems were applied ( $n=8)$ : an etchand-rinse (Adper Single Bond 2 - SB), a "mild" two-step self-etching (Clearfil SE Bond - SE) and a one-step self-etching adhesive system (Futurabond - FB). Each specimen was restored with a composite resin and sectioned into $1.0-\mathrm{mm}^{2}$ thick slabs. After 24 hours, resin-dentin sticks were submitted to tensile stress in a universal testing machine $(0.5 \mathrm{~mm} / \mathrm{min})$. Data were submitted to two-way ANOVA and Tukey's test at a level of $0.05 \%$.

Results: Superficial dentin showed the highest microtensile bond strength values, which differed statistically from those obtained in the deep dentin, irrespective of the adhesive system used. FB yielded the highest bond strength values, which were statistically similar to the bond strength values of SE, but statistically different from those obtained when the SB adhesive was used.

Conclusions: Bond strength obtained in superficial dentin was significantly higher than in deep dentin, for all adhesive systems tested. Adhesion was affected by the different bonding strategies: the one-step, low pH, acetone-based self-etching adhesive promoted the higher bond strength values, which were statistically similar to those obtained with the two-step, water-based self-etching adhesive. (Eur J Dent 2010;4:110-117)

Key words: Bonding; Dentin; Self-etching adhesive; Microtensile bond strength.

a DD, Faculdade de Odontologia e Centro de Pesquisas Odontológicas São Leopoldo Mandic, Campinas, São Paulo, Brazil.

b DDS, MS, Faculdade de Odontologia e Centro de Pesquisas Odontológicas São Leopoldo Mandic, Campinas, São Paulo, Brazil.

c DDS, MS, ScD, Professor, Faculdade de Odontologia e Centro de Pesquisas Odontológicas São Leopoldo Mandic, Campinas, São Paulo, Brazil.

d DDS, MS, PhD, Professor, Faculdade de Odontologia e Centro de Pesquisas Odontológicas São Leopoldo Mandic, Campinas, São Paulo, Brazil.
Corresponding author:

Profa. Dra. Roberta Tarkany Basting

Faculdade de Odontologia e Centro de

Pesquisas Odontológicas São Leopoldo MandicDepartamento de Odontologia

Restauradora - Dentística,

Rua José Rocha Junqueira

13 Bairro Swift,

Campinas - SP

CEP: 13045-755 Brazil.

Phone/Fax: 55-19-3211-3600

E-mail: rbastingdyahoo.com 


\section{INTRODUCTION}

Dentinal tissue continues to represent a challenge as regards bonding with resin-based adhesives, ${ }^{1}$ because of its complexity and dynamism. ${ }^{2}$ This substrate has been characterized as a biologic composite of collagen matrix, filled with apatite crystallites, dispersed between parallel micrometer-sized hypermineralized, collagen-poor dentinal tubules containing peritubular dentin. ${ }^{3}$ In general, $50 \%$ of the chemical composition of dentin substrate is made up of minerals, $20 \%$ of water and $30 \%$ of organic matrix, but it is known that this composition may change according to the depth of tooth. ${ }^{4}$ This is due to the fact that superficial dentin has few tubules and is composed predominantly of intertubular dentin. Deep dentin (near pulp) is composed mainly of larger funnel-shaped dentinal tubules with much less intertubular dentin. ${ }^{5}$

The intertubular dentin plays an important role during hybrid layer formation in superficial dentin, and the contribution to resin retention is proportional to the intertubular dentin available for bonding. ${ }^{6}$ Although the concept of hybrid layers refers to resin-infiltrated demineralized intertubular dentin, the penetration of resin into each dentinal tubule, forming the so-called resin tags, should also be considered for hybrid layer formation. In this context, these tags represent a minor fraction of superficial dentin sealed by resin, but a significant fraction of bonded surfaces in deep dentin. ${ }^{6}$ The contribution of tags to the total bond strength is proportional to their cross-sectional area and the cohesive strength of the polymer. ${ }^{7}$ The relative contribution of resin tags and the relative contribution of hybrid layer to the total bond strength are dependent on dentin depth.

However, not only should these dentinal structures be taken into account, but also the variation of water content that occurs according to the depth of dentin. This is important because a significant water content of dentin is confined to dentinal tubules, and since the density of tubules varies with dentinal depth, it is expected that the water content of dentin is higher in deep dentin and lower in superficial dentin. ${ }^{8}$ This is especially important when considering current adhesive systems which, according to their underlying adhesion strategy, can be classified as "etch-andrinse" and "self-etching", the latter type being subdivided according to its acidity into "strong"
$(\mathrm{pH}<1)$, intermediately strong $(\mathrm{pH} \sim 1,5)$ or "mild" self-etching adhesives ( $\mathrm{pH} 2$ ). ${ }^{9}$

For the etch-and-rinse adhesive systems, basically two steps are required: selective dissolution of hydroxyapatite crystals and exposure of collagen network through etching, followed by in situ resin polymerization. With the aim of determining the contribution of resin infiltration to dentin bond strength using an etch-and-rinse adhesive system on middle dentin, Gwinnett ${ }^{10}$ demonstrated that bond strength to smear layer-covered dentin is approximately half of what it is to smear layer-free dentin, indicating that the smear plug prevented monomer penetration into tubules to form resin tags. Moreover, it was observed that the intertubular dentin remained mineralized and this fact should have prevented the formation of a hybrid layer. In a similar way, the "intermediately strong" and "mild" self-etching adhesive systems are able to demineralize the superficial dentin layer, retaining the residual hydroxyapatite still attached to collagen. But in this case, the remaining hydroxyapatite crystals may be an advantage, because they serve as a receptor for additional chemical bonding with functional monomers contained in some self-etching adhesives. ${ }^{11}$

Moreover, the solvent type (water, acetone, alcohol or an association between them) varies among the different adhesives, the dentin water content, or more specifically the wetness of dentin, being an important factor to achieve optimal bonds. Gianinni et $\mathrm{al}^{12}$ stated that depending on the region where the bond is established and the adhesive system being tested, the dentin depth may affect the bond strength values. Although these authors found that bond strength to middle and deep dentin was lower than it was to superficial dentin, a water-based adhesive system was used, and its performance in a region that has a higher water content, such as deep dentin, may be compromised. Toledano et $\mathrm{al}^{13}$ investigated the bond strength of different adhesive systems to either superficial or deep dentin. They found that the highest values for bond strength to deep dentin were obtained with a water-based self-etching adhesive that contained the functional monomer 10-MDP, and also with an acetone-based etchand-rinse adhesive. The lowest bond strengths were found with the ethanol-based adhesives. This indicates that among other factors, the type 
of solvent may be important for bonding in different regions of the tooth. The acetone solvent may act positively in deep dentin, where the water content is higher, because acetone is the most hydrophilic solvent and is an excellent "water-chaser".14

Therefore, considering the importance of different bonding strategies, composition, acidity, solvent contained in adhesive systems and the influence these factors may have on bond strength to different regions of the tooth, the aim of this in vitro study was to evaluate the microtensile bond strength of a two-step ethanol-based etch-andrinse adhesive system, a "mild" two-step waterbased self-etching adhesive system that has a functional monomer in its composition and a "strong" one-step acetone-based self-etching adhesive system to superficial and deep dentin. The hypotheses tested were that: (1) dentin adhesives bond equally well to superficial and deep permanent dentin; (2) there is no difference between etch-and-rinse and self-etch adhesives in bonding to these respective dentin substrates.

\section{MATERIALS AND METHODS}

Experimental design

The factors under study were dentin depth, at two levels: Superficial dentin (SD) and deep dentin (DD); type of adhesive system, at three sublevels: two-step etch-and-rinse adhesive system (Adper Single Bond 2 (SB), 3M ESPE); two-step self-etching adhesive system (Clearfil SE Bond (SE), Kurarayl and a one-step self-etching adhesive system (Futurabond (FB) / Voco). The association between depth of dentin and type of adhesive system resulted in 6 experimental groups. The experimental sample comprised 48 specimens $(n=8)$. The response variable was microtensile bond strength means, expressed in MPa. The composition and description of each material used in this study are shown in Table 1.

\section{Specimen preparation}

After approval by the Research Ethics Committee (Protocol No.2006/0245), non-erupted human third molars extracted within a six-month period and stored in thymol $(0.1 \%, \mathrm{pH} 7.0)$ immediately after extraction were used in this experiment. Teeth were submitted to debriding with scalpel blades and periodontal curettes.

To obtain superficial dentin (SD), 24 teeth were flattened in a water-cooled polishing machine (Politriz Aropol 2V, Arotec, São Paulo, SP, Brazil) with 400-grit aluminum oxide abrasive paper. The occlusal surface was flattened until a central area of dentin (measuring about $5 \times 5 \mathrm{~mm}$ ) was obtained, with only the central area of the resin-tooth block being used. Dentin surfaces were controlled for the absence of enamel by checking with a stereomicroscope (EK3ST, CQA, São Paulo, Brazil).

To obtain deep dentin (DD), 24 teeth were flattened in a water-cooled polishing machine (Politriz Aropol 2V, Arotec, São Paulo, SP, Brazil) with 400grit aluminum oxide abrasive paper until there was an 1-mm thickness of dentin in the central area next to the pulp (about $5 \times 5 \mathrm{~mm}$ ), measured with a digital caliper (Mitutoyo, Tokyo, Japan).

The pulp chambers were prepared for filling with a composite resin in order to increase the stick lengths and facilitate their fixation to acrylic devices for the microtensile bond strength tests: internal dentine walls were cleaned and etched with a phosphoric acid (Condac 37, lot \#310107, FGM Produtos Odontológicos LTDA, Joinville, SC, Brazill for 15 seconds, washed for the same time and gently dried with absorbent paper. The adhesive system Adper Single Bond 2 (Lot\#6JA, 3M ESPE, St. Paul, USA) was applied in two consecutive layers; the remaining solvent was evaporated with a brief, gentle dry air jet for 10 seconds and light polymerized for 20 seconds. After that, the pulp chamber of each tooth was filled with a composite resin (Filtek Z250, UD color, Lot 7AT, 3M ESPE, St. Paul, USA) using the incremental technique and light polymerized with a halogen light curing unit (Ultralux EL, Dabi Atlante, Ribeirão Preto, SP, Brazill.

Application of adhesive systems

Superficial and deep dentin specimens were randomly divided into three groups according to the adhesive system used ( $n=8)$. All bonding procedures were performed in accordance with the manufacturers' instructions and are described in Table 1. After that, a composite resin block (Filtek Z 250, A1 color, batches \#5AY and \#6YN, 3M ESPE, St. Paul, USA), measuring $5 \times 5 \mathrm{~mm}$ (height $x$ width) was built on the bonding surface, by the incremental technique. Each layer of composite lapproximately 2-mm thick) was individually light polymerized for 40 seconds, with a visible light-curing 
Table 1. Description of materials used in this study.

\begin{tabular}{|c|c|c|c|c|c|}
\hline $\begin{array}{l}\text { Brand name, } \\
\text { manufacturer, } \\
\text { batch number }\end{array}$ & Type of adhesive & Composition* & $\mathrm{pH}^{* *}$ & Solvent & $\begin{array}{l}\text { Instructions for } \\
\text { use }^{* * *}\end{array}$ \\
\hline $\begin{array}{l}\text { Adper Single Bond } 2 \\
\text { (SB) } \\
\text { 3M ESPE, St. Paul, } \\
\text { USA } \\
\text { \# 6JA }\end{array}$ & $\begin{array}{l}\text { Two-step } \\
\text { etch-and-rinse }\end{array}$ & $\begin{array}{l}\text { BISGMA, HEMA, } \\
\text { copolymer of } \\
\text { acrylic and itaconic } \\
\text { acids, water, ethyl } \\
\text { alcohol, glycerol } \\
\text { 1, 3-dimethacry- } \\
\text { late, diurethane } \\
\text { dimethacrylate, } \\
\text { silane treated } \\
\text { silica, water. }\end{array}$ & $\sim 4.3$ & $\begin{array}{l}\text { water, } \\
\text { alcohol }\end{array}$ & $\begin{array}{l}\text { Treat surfaces with } \\
\text { the } 37 \% \text { phosphoric } \\
\text { acid gel for } 15 \mathrm{sec}- \\
\text { onds, rinse for the } \\
\text { same time and gently } \\
\text { dry. Apply the adhe- } \\
\text { sive system in two } \\
\text { consecutive layers; } \\
\text { evaporate the re- } \\
\text { maining solvent with } \\
\text { a brief, gentle dry air } \\
\text { jet for } 10 \text { seconds and } \\
\text { light polymerize for } \\
20 \text { seconds. }\end{array}$ \\
\hline $\begin{array}{l}\text { Clearfil SE Bond (SE) } \\
\text { Kuraray Medical Inc, } \\
\text { Okayama, Japan. } \\
\text { Primer \# } 00727 \text { A } \\
\text { Bond \# } 01044 \text { A }\end{array}$ & $\begin{array}{l}\text { Two-step } \\
\text { self-etch }\end{array}$ & $\begin{array}{l}\text { Primer: 10-MDP, } \\
\text { HEMA, hydrophilic } \\
\text { dimethacrylate, di- } \\
\text { Camphorquinone, } \\
\text { N, N Diethanol-p- } \\
\text { toluidine, water. } \\
\text { Bond: 10-MDP, } \\
\text { BISGMA, HEMA, } \\
\text { hydrophobic di- } \\
\text { methacrylate, di- } \\
\text { Camphorquinone, } \\
\text { N,N Diethanol-p- } \\
\text { toluidine, Silinated } \\
\text { colloidal silica. }\end{array}$ & $\sim 2.1$ & water & $\begin{array}{l}\text { Apply primer and } \\
\text { leave it in place for } 20 \\
\text { seconds, evaporate } \\
\text { volatile ingredients } \\
\text { with a mild oil-free } \\
\text { air stream. Then, } \\
\text { apply bond, gently dry } \\
\text { air and light-cure for } \\
10 \text { seconds. }\end{array}$ \\
\hline $\begin{array}{l}\text { Futurabond (FB) } \\
\text { Voco GmbH, Germany } \\
\text { Liquid A \# } 611090 \\
\text { Liquid B \# } 611091\end{array}$ & $\begin{array}{l}\text { One-step } \\
\text { self-etch }\end{array}$ & $\begin{array}{c}\text { BISGMA, BHT, } \\
\text { acetone, diureth- } \\
\text { anemethacrylate, } \\
\text { HEMA, organic } \\
\text { acids. }\end{array}$ & $\sim 1$ & acetone & $\begin{array}{l}\text { Dispense one drop of } \\
\text { each agent into the } \\
\text { mixing capsule, mix } \\
\text { the two agents, apply } \\
\text { the mixture to the } \\
\text { dental structure for } \\
20 \text { seconds, dry and } \\
\text { light polymerize for } \\
10 \text { seconds. }\end{array}$ \\
\hline
\end{tabular}

* Based on information provided by manufacturers: Bis-GMA: Bisphenol A diglycidyl ether dimethacrylate; HEMA: 2- hydroxyethyl methacrylate; MDP: 10- Methacryloyloxydecyl duhydrogen phosphate, BHT: butylated hydroxyl toluene.

** Osorio et al. (2008).

*** Based on manufacture's recommendations. 
unit (Ultralux EL, Dabi Atlante, Ribeirão Preto, SP, Brazil). Finally, the restoration was light polymerized for 20 seconds on each of its two sides. The light-curing unit output was periodically measured with a radiometer (Newdent Equipamentos Ltda, Ribeirão Preto, SP, Brazil) with a mean range of $620 \mathrm{~mW} / \mathrm{cm}^{2}$. Throughout specimen processing, care was taken to avoid dehydration of the samples.

Microtensile bond strength ( $\mu$ TBS) testing

Tooth-resin blocks were sectioned perpendicular to the bonding surface into $1.0-\mathrm{mm}$ thick slabs, using a water-cooled diamond disc in a sectioning machine (Minitrom, Struers A/S, Copenhagen, Denmark). By rotating samples $90^{\circ}$ and again sectioning them lengthwise, multiple beam-shaped sticks were obtained, each with a cross-sectional surface area of $1.0 \mathrm{~mm}^{2}$.

Sticks were kept in distilled water at $37^{\circ} \mathrm{C}$, for 24 hours. Subsequently they were individually measured with a digital caliper (Mitutoyo, Tokyo, Japan) and attached to a device specifically for $\mu$ TBS testing, with a cyanoacrylate adhesive (Super Bonder Gel, Henkel Ltda., Brazil). They were subjected to tensile stress in a universal testing machine (MEM-2.000 model, EMIC, São José dos Pinhais, PR, Brazil), at a crosshead speed of 0.5 $\mathrm{mm} / \mathrm{min}$ and a $50 \mathrm{~N}$ load cell until fracture. The bond strength values were reported in $\mathrm{MPa}$ and derived by dividing the imposed force (in Kgf) at the time of fracture by the bond area $\left(\mathrm{cm}^{2}\right)$. When the specimens failed before actual testing, the $\mu$ TBS was determined from the specimens that survived processing. Comparison was made by using the mean of each tooth (6 sticks per tooth).

Fractured specimens were observed under a stereomicroscope (EK3ST, CQA, São Paulo, Brazil) at $30 x$ magnification to assess the failure modes, which were classified as adhesive llack of adhesion), cohesive in dentin (failure of the dental substrate), cohesive in composite resin (failure of the resin composite) or mixed (adhesive and cohesive failures).

Means and standard deviations were calculated, and the data were analyzed by two-way analysis of variance (ANOVA). Multiple comparisons were made by Tukey's test at a 0.05 significance level.

\section{RESULTS}

Considering the dentin depth, data analysis revealed that the superficial dentin showed the highest microtensile bond strength values, which differed statistically from those obtained in the deep dentin, irrespective of the adhesive system used (Table 2 and Figure 1).

For both superficial and deep dentin, Futurabond yielded the highest bond strength values, which were statistically similar to the bond strength values of Clearfil SE Bond, but statistically different from those obtained when the Single Bond adhesive system was used. Clearfil Se Bond and Adper Single Bond 2 adhesive systems presented statistically similar bond strength values between them.

Considering the fractures of specimens (Table 3), all groups showed a predominance of adhesive fractures, with a minor fraction of fractures occurring in the resin (cohesive in composite resin). None of fractures were classified as cohesive in dentin or mixed linvolving dentin and composite resin).

\section{DISCUSSION}

The results of the present study revealed that superficial dentin presented bond strength values that were statistically higher and different from values obtained in deep dentin. Thus, the first hypothesis was rejected. Theoretically, the bond strength of dentin-bonding agents at any depth is dependent on the area occupied by resin tags, the area of intertubular dentin that is infiltrated by the resin and the area of surface adhesion. ${ }^{13}$ But, even if deep dentin were capable of producing higher bond strengths due to an increase in the total surface area available for forming hybridized tubule walls and intertubular dentin, the opposite has been found. ${ }^{12,15-17}$ Toledano et $\mathrm{al}^{13}$ speculated that even in the absence of dentin perfusion, contemporary adhesives may produce variable bonding results in superficial and deep dentin due to variations in their composition and the bonding approach.

Considering the adhesive systems and the depth of dentin, the results of the present study showed differences in bond strength of the tested adhesives, with the type of solvent and the $\mathrm{pH}$ of the adhesive system being important for the achievement of good bond strength to dentin. 
Therefore, the second hypothesis was also rejected. Although the application of Futurabond selfetching adhesive was incapable of yielding similar bond strength values between deep and superficial dentin, it yielded the highest bond strength values when the adhesive systems were compared in isolation. These values were statistically similar to those obtained when the Clearfil SE Bond self-etching adhesive was used. Futurabond is a one-step self-etching adhesive consisting of organic acid combined with hydrophobic monomers and HEMA, all dissolved in acetone. Self-etching adhesive systems have been referred to as being "user-friendly" and less technique-sensitive because this approach eliminates the rinsing phase and the risk of making errors during application. ${ }^{18}$

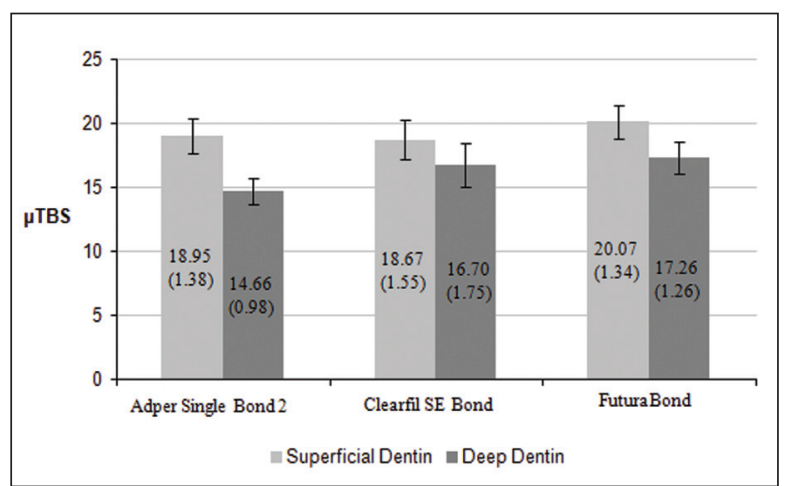

Figure 1. Means (standard deviations) of each experimental group.
This may have acted as a factor that influenced the results to some extent. Moreover, the acetone solvent present in the Futurabond adhesive is an excellent "water-chaser", capable of avoiding residual water in dentin during its application. Even when there are relatively few tags, such as in superficial dentin, they may be important for resin retention. But polymer tags could contribute to this retention if they are firmly attached to the walls of tubules. ${ }^{6}$ For this to occur, the peritubular dentinal matrix must be removed to expose the circumferentially oriented collagen fibrils. The aggressiveness of Futurabond, represented by its low $\mathrm{pH}$, may have acted positively by demineralizing the dentin matrix and probably helping the tags to bond to the exposed collagen inside the tubules. Toledano et al $^{19}$ stated that prolonging the time between adhesive application and drying should be considered in order to increase dentin bond strength, because it probably resulted in more optimal water permeation within this adhesive, contributing to a more complete dissociation of the acid functional monomers, and enhancement of the resin monomer infiltration. This was not considered in the present study, but the acetone-based adhesive could perform differently in deep dentin, if alternative bonding strategies were used instead of the manufacturer's instructions.

Table 2. Microtensile bond strength means (MPa) and standard deviations in each experimental group.

\begin{tabular}{lccc}
\hline Adhesives & Superficial dentin & Deep dentin & Tukey \\
\hline Adper Single Bond 2(SB) & 18.95 (1.38) A & $14.66(0.98) \mathrm{B}$ & $\mathrm{b}$ \\
Clearfil SE Bond (SE) & 18.67 (1.55) A & $16.70(1.75) \mathrm{B}$ & $\mathrm{ab}$ \\
Futurabond (FB) & 20.07 (1.34) A & $17.26(1.26) \mathrm{B}$ & $\mathrm{a}$ \\
\hline
\end{tabular}

Means followed by the same letter (capital in the horizontal, lower case letters in the vertical) are not statistically different $(P<.05)$.

Table 3. Percentage (and number) of fracture types of $\mu$ TBS samples as analyzed by stereo-microscopy.

\begin{tabular}{|c|c|c|c|c|c|c|}
\hline & $\begin{array}{c}\text { SB } \\
\text { superficial }\end{array}$ & $\begin{array}{c}\text { SE } \\
\text { superficial }\end{array}$ & $\begin{array}{c}\text { FB } \\
\text { superficial }\end{array}$ & $\begin{array}{c}\text { SB } \\
\text { deep }\end{array}$ & $\begin{array}{c}\text { SE } \\
\text { deep }\end{array}$ & $\begin{array}{c}\text { FB } \\
\text { deep }\end{array}$ \\
\hline Adhesive & 88.10 (37) & $90.48(38)$ & $90.48(38)$ & $97.62(41)$ & $100.00(42)$ & $97.62(41)$ \\
\hline Cohesive resin & $11.90(5)$ & $9.52(4)$ & $9.52(4)$ & $2.38(1)$ & $0.00(0)$ & $2.38(1)$ \\
\hline Cohesive dentin & $0.00(0)$ & $0.00(0)$ & $0.00(0)$ & $0.00(0)$ & $0.00(0)$ & $0.00(0)$ \\
\hline Mixed & 0.00 & 0.01 & 0.02 & 0.03 & 0.04 & 0.05 \\
\hline
\end{tabular}


Although the water-based Clearfil SE Bond adhesive does not have a low $\mathrm{pH}$ and is classified as being moderately aggressive $(\mathrm{pH} \sim 2.1)$, the bond strength values of this adhesive to both deep and superficial dentin were statistically similar to those of the Futurabond group. The Clearfil SE Bond has an acidic primer that is applied, followed by the application of the bond resin, without the rinsing phase. This low-sensitive technique, similar to that of Futurabond, could be a factor that really influenced bonding to dentin. In addition to forming a micromechanical bond to dentin, this adhesive system is believed to incorporate a chemical interaction with the calcium in dentin because of the 10-MDP functional monomer, which has been rated as the most promising monomer for chemical bonding to the hydroxyapatite of enamel or dentin. ${ }^{20}$ Perdigão et al ${ }^{21}$ stated that Clearfil SE Bond is capable of providing consistently strong bonds to enamel and dentin, and the good performance of this adhesive system may be partly attributed to the intense chemical bond to tooth tissue. ${ }^{11}$

The two-step etch and rinse Adper Single Bond 2 adhesive, which has the more sensitive technique, yielded statistically similar bond strength values to those obtained with the Clearfil SE Bond, but different from the FuturaBond values, this difference being most evident in deep dentin. Once again, increasing the sensitivity of the bonding technique, because of the conditioning and rinsing steps, may lead to more operating errors. This occurs because the ideal situation, in which this adhesive system completely penetrates demineralized dentin, is more difficult to achieve. ${ }^{9}$ The results of Adper Single Bond 2 adhesive system in deep dentin can also be attributed to its specific composition, because this adhesive contains water and ethanol as solvents. Toledano et al13 observed extensive nanoleakage with this adhesive and the authors stated that the presence of HEMA in this adhesive can lower the vapor pressure of water, with the water being more difficult to remove ${ }^{22}$ from demineralized deep dentin, thus impairing the diffusion of the bisphenol A diglycidyl ether dimethacrylate (Bis-GMA) resin monomer. This may not occur with the acetone-based adhesives. Moreover, incomplete resin infiltration can be caused by the acid copolymer, ${ }^{22}$ a component incorporated into the composition of Adper Single Bond 2.
The aim of the present study was to evaluate the influence of different bonding strategies on the bond to deep and superficial dentin, but bonding tests were performed 24 hours after the restorations were done. However, the durability of bonds between the adhesive system and dentin is of critical importance for the longevity of restorations because of the degradation that occurs at the adhesive interface. With respect to this factor, Osorio et $\mathrm{al}^{23}$ demonstrated that self-etching adhesives with a $\mathrm{pH}<1$ and containing water or acetone as solvent yielded catastrophic bond failure after 1 year of water storage. Therefore, although the results obtained in this study demonstrated good prospects for self-etching adhesives, their performance in a long-term degradation process should be carefully evaluated.

\section{CONCLUSIONS}

- Bond strength obtained in superficial dentin was significantly higher than in deep dentin, for all adhesive systems tested.

- Bonding to different regions of the tooth may be influenced by the type of solvent, with the acetone solvent from one-step adhesives being more indicated for achieving good bonding, particularly in deep dentin; and by the presence of functional monomers (such as the 10-MDP) in water-based adhesives. Although the bond strength of the etchand-rinse adhesive system did not attain the values of the one-step acetone-based adhesive, its values were comparable with those of the twostep, water-based adhesive.

\section{REFERENCES}

1. Perdigão J, Frankenberger R, Rosa BT, Breschi L. New trends in dentin/enamel adhesion. Am J Dent 2000;13 ISpec Issue):25D-30D.

2. Pashley DH. Dentin: A dynamic substrate. Review. Scanning Microsc 1989;3:161-176.

3. Marshall GW Jr, Marshall SJ, Kinney JH, Balooch M. The dentin substrate: Structure and properties related to bonding. J Dent 1997;25:441-458.

4. Panighi M, G'Sell $C$. Effect of tooth microstructure on the shear bond strength of a dental composite. J Biomed Mater Res 1993;27:975-981.

5. Garberoglio R, Brännström M. Scanning electron microscopic investigation of human dentinal tubules. Arch Oral Biol 1976;21:355-362 
6. Nakabayashi N, Pashley DH. Characterization of the hybrid layer. In Nakabayashi N, Pashley DH. Hybridization of dental hard tissues. Tokyo: Quintessence Publishing Co, Ltd 1998;57-85

7. Nakabayashi N. Bonding of restorative materials to dentine: The present status in Japan. Int Dent J 1985;35:145154.

8. Pashley $\mathrm{DH}$. The clinical correlations of dentin structure and function. J Prosthet Dent 1991;66:777-781.

9. Van Meerbeek B, De Munck J, Yoshida Y, Inoue S, Vargas $M$, Vijay $P$, Van Landuyt $K$, Lambrechts $P$, Vanherle $G$. Buonocore memorial lecture. Adhesion to enamel and dentin: current status and future challenges. Oper Dent 2003;28:215-235.

10. Gwinnett AJ. Quantitative contribution of resin infiltration/ hybridization to dentin bonding. Am J Dent 1993;6:7-9.

11. Van Landuyt KL, Snauwaert J, De Munck J, Peumans M, Yoshida Y, Poitevin A, Coutinho E, Suzuki K, Lambrechts $P$, Van Meerbeek B. Systematic review of the chemical composition of contemporary dental adhesives. Biomaterials 2007;28:3757-3785

12. Giannini M, Reis AF, Arrais CAG. Effect of dentinal depth on the tensile bond strength of a self-etching adhesive system. $R P G$ rev. pos-grad 2002;9:43-50.

13. Toledano M, Osorio R, Ceballos L, Fuentes MV, Fernandes CA, Tay FR, Carvalho RM. Microtensile bond strength of several adhesive systems to different dentin depths. Am J Dent 2003;16:292-298.

14. Van Meerbeek B, Vargas S, Inoue S, Yoshida Y, Peumans M, Lambrechts P, Vanherle G. Adhesives and cements to promote preservation dentistry. Oper Dent 2001;Suppl 6:119144.

15. Tagami J, Tao L, Pashley DH. Correlation among dentin depth permeability and bond strength of adhesive resins. Dent Mater 1990;6:45-50.

16. Pashley EL, Tao L, Matthews WG, Pashley DH. Bond strengths to superficial, intermediate and deep dentin in vivo with four dentin bonding systems. Dent Mater 1993;9:19-22.

17. Lopes GC, Perdigão J, Lopes Mde F, Vieira LC, Baratieri LN, Monteiro S Jr. Dentin bond strengths of simplified adhesives: effect of dentin depth. Compend Contin Educ Dent 2006;27:340-345.

18. De Munck J, Van Landuyt K, Peumans M, Poitevin A, Lambrechts $P$, Braem M, Van Meerbeek B. A critical review of the durability of adhesion to tooth tissue: methods and results. J Dent Res 2005;84:118-132.

19. Toledano M, Proença JP, Erhardt MC, Osorio E, Aguilera FS, Osorio R, Tay FR. Increases in dentin-bond strength if doubling application time of an acetone-containing onestep adhesive. Oper Dent 2007;32:133-137.
20. Yoshida Y, Nagakane K, Fukuda R, Nakayama Y, Okazaki M, Shintani H, Inoue S, Tagawa Y, Suzuki K, De Munck J, Van Meerbeek B.. Comparative study on adhesive performance of functional monomers. J Dent Res 2004;83:454-458.

21. Perdigão J, Gomes G, Gondo R, Fundingsland JW. In vitro bonding performance of all-in-one adhesives. Part I--microtensile bond strengths. J Adhes Dent 2006;8:367-373.

22. Spencer P, Wang Y, Walker MP, Wielczka DM. Interfacial chemistry of the dentin/adhesive bond. J Dent Res 2000;16:406-411.

23. Osorio R, Pisani-Proenca J, Erhardt MC, Osorio E, Aguilera FS, Tay FR, Toledano M. Resistance of ten contemporary adhesives to resin-dentine bond degradation. J Dent 2008;36:163-169 